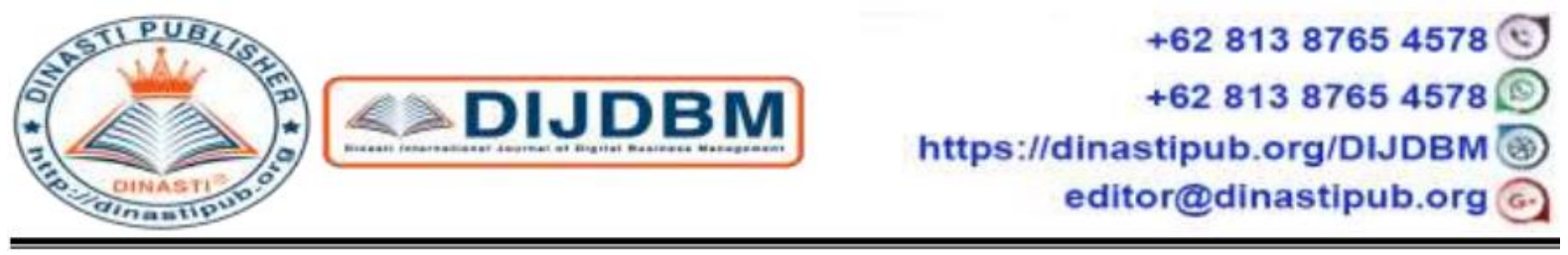

\title{
OVERCOMING OBSTACLES IN THE DEVELOPMENT OF IKRT / UMK THROUGH APPLICATION OF APPROPRIATE TECHNOLOGY
}

\section{Gusti Ayu Arwati' ${ }^{1)}$, Euis Nina Saparina ${ }^{2)}$, Nur Endah Retno Wuryandari ${ }^{3)}$}

${ }^{1,2,3)}$ Lecturers of Universitas Mercu Buana, Jakarta, Indonesia

\begin{tabular}{c} 
ARTICLE INFORMATION \\
Received: 3rd March 2020 \\
Revised: 15th April 2020 \\
Issued: 28th April 2020 \\
Corresponding author: \\
I Gusti Ayu Arwati \\
E-mail: \\
ayuarwati@mercubuana.ac.id \\
nurendah.retno@mercubuana.ac.id \\
\hline
\end{tabular}

DOI:10.31933/DIJDBM
Abstract: The SME sector that has an important role in the Indonesian industry is the small and home industry (IKRT) or micro and small businesses (MSME). In everyday life, washing clothes and washing the house is an activity that is usually done by everyone, especially by the home industry. IKRT (UMK) Suradita RW 09 Suradita Indah Complex, is IKRT (UMK) in the Suradita sub-district, which produces green cleaning products guided by Universitas Mercu Buana lecturers who have been operating for one year. IKRT (UMK) was established to increase the knowledge of housewives who live in RW 09, where production is marketed in the surrounding area as well. In addition there is no good management governance, also a good marketing strategy. Based on the above, the objectives of community service are (1) using appropriate technology in the green cleaner production process, (2) improving the quality of green cleaner product formulations, (3) implementing good governance management and marketing strategies to be more effective and efficient and has sustainable competitiveness. The results of this community service are (1) appropriate technology that can be used in the production process. (2) Improving the quality of green cleaner product formulations and (3) governance management and marketing strategies. And can avoid Suradita IKRT which is more effective and efficient and has sustainable competitiveness.

Keywords: IKRT, Green Cleaners, Appropriate Technology, Governance Management, Marketing Strategy for SME.

\section{INTRODUCTION}

In daily life, washing clothes and cleaning house are common daily chores executed by all people especially household. The fact is, all these past years, those activities use 
synthetic -based cleaner. On the other hand, as it is used in the needs of house cleaning, it also gives negative effect for the health of the users and the surrounding environment. As the example, the type of detergent that is used the most in the household is ABS-based detergent (alkyl benzene sulphonate) which is categorized as harsh material.

The detergent is hard to be decomposed by microorganism (non-biodegradable) which then affects the environmental pollution [5]. Irrigation environmental that is polluted the said high-concentrated harsh material detergent can threaten towards the life cycle inside the irrigation and the human who consumes the seafood or any food product related. [1] it is stated that the compounds contained in the detergent can cause health problem. One of the examples is skin irritation that is arose with heat and dryness on hand skin, blister, chapped skin, fragile, furthermore is itchy skin and sometimes cause allergy, cataract on adult's eyes. The environmental impact can be seen on foam on the surface of irrigation which decreases the oxygen consent on the water. This leftover detergent waste as the rest of household daily use can be hazardous waste and threaten the sustainability of environmental stability.

It is important for producers to develop Halal product which meet the Halal requirements and criteria including green cleaner due to the fact that the detergent that is sold in the market uses hazardous material that impacts negatively on health and surrounding environment. Thus, the development of green cleaner product that is safe for environment (green clean environment) which is effective for cleaning use, hygiene and safe for health and surrounding environment. This is one of potential business opportunity for Usaha Mikro Kecil (Micro Business Scale) and Industri Kecil Rumah Tangga (Home Industry Scale) to develop the business of green clean product.

The existence of Usaha Mikro, Kecil dan Menengah (UMKM / Micro-Scale, SmallScale and Middle-Scale Business Industry) in Indonesia have great potential that is strategic in greater the local economy growth, especially in giving job opportunities and contribution towards national income. According to the data of the Ministry, the total of UMKM in Indonesia on 2012 was 56,53 million units and gave job opportunities for laboring about 97,16 percent $(107,65$ million people) contributing to domestic product in national scale for 59,08 percent (IDR 4.869 trillion).

The development of UMKM gradually increased every year along with growth percentage 2,3 percent each year from 2007 until 2012. One of the UMKM sectors which took significant role for national scale in Indonesia was small scale industry and Home Industry (IKRT) or UMK (Micro Business Scale). To be more detail for each percentage from the whole percentage, 99,9 percent was the UMK (Micro Business Scale) which consisted of 98,79 percent usaha mikro (Micro Scale Industry) and 1,11 percent was usaha kecil (small scale industry). It is an indicator that IKRT has great impact in strategic role for the economic growth in Indonesia, especially greater the economic growth in village area [9]. Several characteristics of IKRT are: (1) Becoming labor intensive business which expected can be a job field for hiring labor in village area, (2) The beginning capital which does not need big amount of money, (3) Using simple technology as equipment, (4) The circulation and distribution of local industry in the village can use local resource and raw material.

\section{The Profile of IKRT (UMK) Suradita}

IKRT (UMK) Suradita RW 09, Suradita Complex is located in Suradita sub-district, is an UMK under the guidance of Mercu Buana University lecturers, since this community service was formed on 2017 financed by internal fund raising from Mercu Buana Univerity, this activity is still operating in current. IKRT was established by Ketua Rukun Warga (Hamlet/Neighborhood Leader) as micro scale industry / business to empower the 
housewives earning income. The products are green cleaner product, which is divided into green detergent and karbol sereh (lemongrass carbolic). Green Clean Detergent has three functions, they are removing and cleaning dirt also perfuming clothes meanwhile karbol sereh is used to clean the floor and can be functioned as disinfectant of fungi, bacteria and some harmful animals (cockroach, ant, fly and so on). Those products are made from safe and non-chemical materials which do give negative impact to the user and surrounding environment. After all this time, this guidance based IKRT (UMK) produces those items with the capacity of 500 liter per month, which can generate 100 jerry cans, each is 5 Liter per jerry can. The green products are marketed to the surrounding residence.

\section{The Potential IKRT SR 09 to Become Job Field}

Currently, the business of green detergent and floor cleaner starts developing as the raising of people's awareness for the importance of saving the environment. Several brands of green cleaner already distributed in the market with various prices and qualities. The brand of products of IKRT SR RW 09 is named Green Cleaner SR, where the quality of product is able to compete and the price can be categorized as lower than others. It makes the customers of Green Cleaner SR stays loyal using this product, even some of them become small scale agent to be then selling the product for other consumers. Based on the information circulated from one to another (words of mouth) about the quality and its safety towards environment, health, and the low price, this time the demands of the green products gets higher, even the distributions expands beyond Suradita sub-district. This situation opens job field for labor hiring as for the development of IKRT Suradita which becomes more potential and gives benefit for the housewives of IKRT Suradita and society. Several reasons why this business needs to be developed are:

1) Supply demand of consumers gains higher, because green cleaner product is proven safe, healthy and hygiene

2) Increasing the income is derived the housewives of IKRT Suradita

3) The expanding of distribution area also the large quantity purchase by Hospitals, Schools and certain instances.

\section{Management and Production Group}

The Industry IKRT Suradita RW 09 can be classified becomes production division, management division and simple technology. The products they make is 2 types, they are (1) liquid detergent 3 in 1 (the functions are cleaning, smoothing and perfuming), (2) karbol sereh (lemongrass carbolic), which the function are to exterminate cockroach, bacteria, insects, mosquitos and make cleaner and healthier environment. All this time, these products are produced or made manually with simple tools by human power.

The said process (simple tools and human power) leads into the situation that can be considered as less optimal and limited production capacity. For the management itself, they do simple and basic method for the financial and benefit record. The administration uses conventional method and the marketing process is only executed in the surrounding areas and insufficient promotion, using words of mouth among the consumers. Based on the said situation, there are many things that supposed to be done, they are (1) developing and contriving the appropriate technology for the production process on green cleaner in order to greater the production capacity so that the production can run effectively and efficiently, (2) improving and developing the formulation of green cleaner to produce supreme and hygiene green cleaner, (3) developing the management system and bettering the marketing strategy to be more effective and efficient. 
Based on the explained problems, it can be identified that the problems found in the IKRT Suradita RW 09 are:

1) As explained above, to run the business precisely there are many things that needs to be improved in several sides, they are material supplies (capital fund), marketing, equipment and packaging. The community service team has tried to direct the members of IKRT Suradita RW 09 many solutions to solve the explained problems. The needs of improving the green cleaner product formulation that is more hygiene and safe for human's health and environment.

2) Insufficient sophistication of management system practice and marketing strategy that is effective and efficient.

\section{RESEARCH METHODS}

The problem solving that is faced by IKRT Suradita RW 09 will be executed by applying the appropriate technology on the production process, improving the quality of green cleaner product quality formulation, improving management system and marketing strategy of green product cleaner. The output that is derived will then be transferred to the IKRT Suradita RW 09 by training, guiding and directing the systems application. Above is the steps carried out by the Universitas Mercu Buana lecturers.

Based on the beginning of research and interview executed by the IKRT Suradita, the inferred that the core of the problem came from production capacity and limited marketing as the production process is implemented by manual process with only simple equipment. This leads into the situation of improving the formulation of green product to be more qualified, safe and hygiene for humans and environment. This community service activity is performed with four steps, they are preliminary step, technology designing step, formulation improving quality step and laboratory testing step, management system planning step, and marketing step along with implementation step.

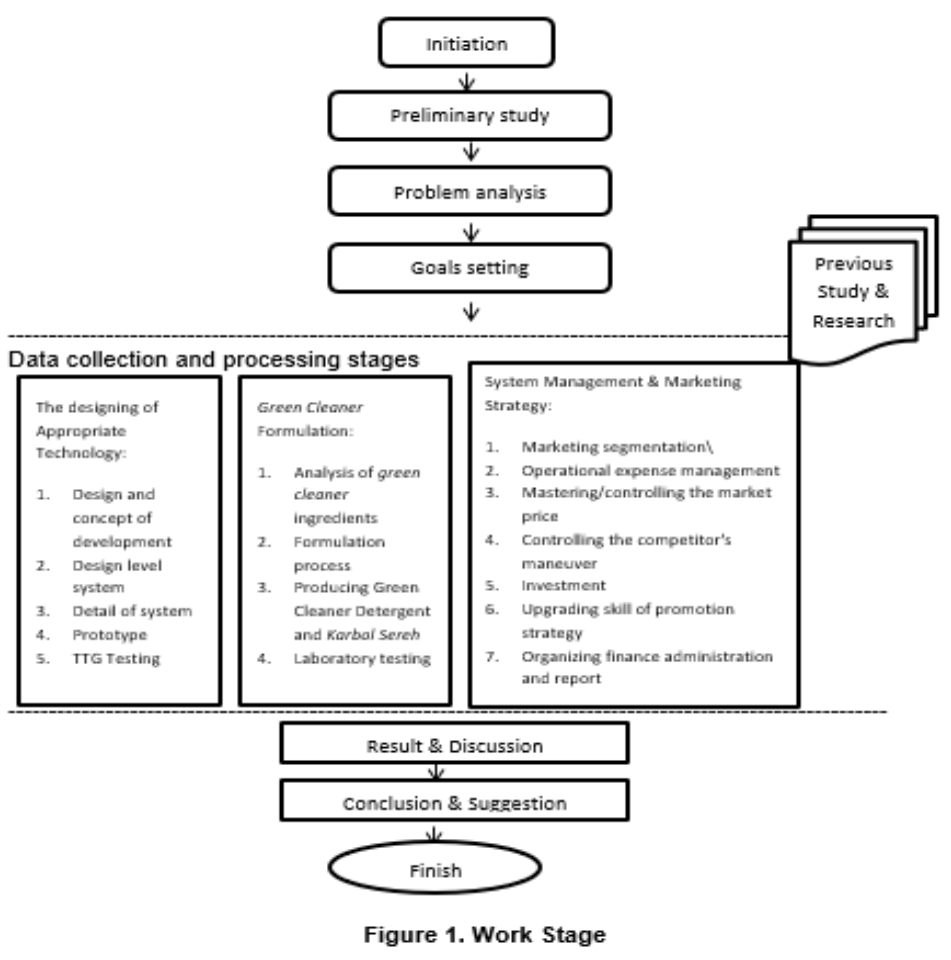




\section{Preliminary Step}

This step carries out observation towards UMK SR by performing:

a) Survey by interviewing to find out the external and internal condition of IKRT SR

b) Identifying the problems faced by IKRT Suradita

\section{Designing Appropriate Technology Step}

This step is executed by designing the appropriate mixer machine for stirring green cleaner ingredients.

Based on the problem faced by IKRT Suradita, this community service attempts to design the appropriate technology for mixer machine to process the production of green cleaner product.

\section{Formulation Improving Quality Step}

In this step, the green cleaner product formulation will be improved based on the purpose to get more qualified, safe and hygiene to humans and environment. Then the formulation will be brought to laboratory to be tested. This final step is performed to fulfill the requirements of Standar Nasional Indonesia (SNI).

\section{Management System Planning Step}

This step develops the business management system starting from planning, performing, controlling and marketing strategy.

\section{TTG Implementation and Formulation Step}

In this step, the green cleaner product as result of appropriate technology improvement will be tested. The formulation that passed the laboratory test will be proven in production process along with the system management and marketing strategy. The steps are:

a. Introduction and application of mixer machine to mix/blend the ingredients to process the green cleaner product as appropriate technology.

b. The application of green cleaner product new formulation.

c. The application of management system and marketing strategy.

d. Socialization and guidance to the production process and marketing to get improvement.

This community service cooperates with several institutions. They are:

1. IKRT (UMK) Green Cleaner in Tangerang, acts as community service towards society.

2. Mechanical Engineering Study Program, Industrial Engineering Study Program, Engineering Faculty, Management Study Program, Business and Economy Faculty also P2M of Mercu Buana University as the communicator between the purpose of community service opinion (DP2M Dikti) with the proposer.

a) LIPI Laboratory as the laboratory test and green cleaner formulation analyst.

b) DP2M Dikti as the facilitator of finance and place for community service proposal.

\section{FINDINGS AND DISCUSSION}


As explained above, there are several things to be improved to run a business, starting from the first step (1) survey observation from UMK SR by interviewing with perpetrator team. They explained the problem they had where they cannot fulfill the market demand as they produce the green cleaner product manually helped with simple equipment only.

From the survey, the team empowers them to earn income where they produce green cleaner, which are divided into green detergent and karbol sereh (carbolic lemongrass). Green Clean Detergent has three functions, they are removing and cleaning dirt also perfuming clothes meanwhile karbol sereh is used to clean the floor and can be functioned as disinfectant of fungi, bacteria and some harmful animals (cockroach, ant, fly and so on). Those products are made from safe and non-chemical materials which do give negative impact to the user and surrounding environment. During this time, IKRT (UMK) Suradita produces those products with the capacity of 100 jerry cans which contain 5 Liter per jerry can, this can be seen in picture $4 \mathrm{~B}$, they produce those green cleaner products by using conventional equipment and quite simple.

The next thing is that from the activity result of this community service urges to solve this problem by creating appropriate technology.

\section{a. The design of mixer machine for green cleaner product ingredients as the appropriate technology}

Based on the problems faced by the IKRT Suradita, the solution of this community service is to create the appropriate technology (mixer machine) to mix the ingredients of green cleaner product as seen on picture $2 \mathrm{~A}$. By using this mixer machine, the production result will increase until 100\% where the quantity is expected to reach 1 ton per week, where this will give benefit for the IKRT Suradita member to earn income and improve their life on economic side.

Furthermore, the improvement of production result of the green detergent and karbol sereh is expected to give job field for those who are unemployed and live around the Suradita village. They can sell the product with the motorcycle they have, going around from one residence area to other area even the conventional market beyond Suradita village.

\section{b. Improving the Quality of Green Cleaner Product Quality Formulation and Laboratory Test}

In this step, the formulation of green cleaner product will be improved by the purpose of better quality, safety and does not give harmful effect to humans and environment. The improvement of formulation can be carried out by completing the devise of water distillation (as seen on picture 7), where this device is used to get standardized water and clean and can produce TDS level under $100 \mathrm{ppm}$, compatible as suggestion from Undang-Undang Kesehatan RI (Indonesian Law of Health). The next is that the formulation will be tested in laboratory to fulfill the Standar Nasional Indonesia (SNI).

\section{c. The Application of Management System and Marketing Strategy}

This step develops the business management system and marketing strategy inside the UKM SR team as seen on picture 8 with the ways above:

a) Market segmentation. This is meant to aim bigger scale of market sorting of government institutions and private institutions (hospitals, schools, regional government and others). 
b) Managing operational expense to control to budget by managing it with the easiest way. Making sure and checking all lowest fare for operational expense due to the limited capital scale.

c) Keep comparing the prices. By controlling and keep comparing the development of prices, whether the price of green cleaner product ingredients or the operational needs. The increasing price of raw material, transportation expense and the same product price from the competitors.

d) Monitoring the competitors. This needs to be concerned all the times. Trying to create excellence comparing to other same products. The examples are product excellence and innovations in marketing.

e) Investment. This means the improvement of business capacity by using appropriate machine as planned in this proposal. Also expanding the network (distribution area) of market place to greater benefit.

f) Upgrading the skill of promotion strategy by using advertisement on social media, web and brochure, marketing strategy on event like bazar.

g) Organizing administration and reporting the inventory of products, marketing and income.

\section{CONCLUSION AND SUGGESTION}

The potentiality of developing the green clean product is also executed by giving concern to Halal product criteria, UMK SR that is located in Cisauk village is actually quite prospective because the people's awareness towards the non-chemical cleaner using is important as it is made from natural (non-hazardous) material and safe ingredients so it will not be harmful and purposed to keep environment and consumer healthy.

The result of product that is safe for environment becomes one important core of consumers' desire also the affordable price, where green product is sold in lower price than others cleaner in the market. From the increasing production so is the marketing will be, which means better potential income earning for UKM-SR team and decreasing the amount of unemployed people in surrounding area of Cisauk village.

During this time, the result of production produced by UKM-SR is only 500 Liter per month, after the existence of appropriate technology prepared by lecturers team and university students (Mercu Buana University), the production increases $100 \%$ even the time to reach the result 1 ton can be shorter, only 2 weeks needed. Besides, another plus point is the water used in this process is more hygiene as it is came from distillation water as purifier.

\section{REFERENCE}

Ariani A. 2013. Pemanfaatan Saponin Daun Akasia ( Acacia auriculiformis A.cunn) sebagai Pembusa Alami dan Agensia Anti Bakteri dalam Sabun Cair. Skripisi. Universitas Kristen Satya Wacana, Salatiga.

Chasani M., Purwati, Widyaningsih S. dan Larasati B. 2013. Hypoglycemic Activity of Aqueous Leaf Extract of Persea americana Mill, Indian J Pharmacol, 37(5), 325-326

Fauziah, N. I. 2010. Formulasi Deterjen Berbahan Aktif Etil Ester Sulfonate dari Minyak Biji Ketapang (Terminali cattapa). Jurnal Sains dan Teknologi Kimia, 4(2), 142-146.

Rahman, A. A., Lelono G. S dan Djaeni M. 2013. Optimalisasi Konsentrasi Ekstrak Saponin Daun Petai Cina (Leucaena leucocephala (Lam.) DeWit.) sebagai Agensia Pembusa Alami Sampo, Seminar Nasional Kimia dan Pendidikan Kimia, Program Studi Kimia Fakultas Sains dan Matematika, Universitas Kristen Satya Wacana (UKSW) Salatiga. 
Rifky Luvia Yuliani, Elly Purwanti, Yuni Pantiwati. Pengaruh Limbah Detergen Indstri Laundry terhadap Mortalitas dan Indeks Fisiologi Ikan Nila (Oreochromis niloticus) https://media.neliti.com/media/publications/176111-ID-none.pdf

Standar Nasional Indonesia. 2008. SNI 7381-2008 Tentang Minyak Kelapa Virgin (VCO). Jakarta: Dewan Standardisasi Nasional.

Wijana, S., Mustaniroh, S. A. dan Wahyuningrum, I. 2005. Pemanfaatan Minyak Goreng Bekas untuk Pembuatan Sabun: Kajian Lama Penyabunan dan Konsentrasi Dekstrin. Jurnal Tek. Per., (3): 193-202.

Yui, Y. H. 1996. Bailey's Industrial Oil and Fat products. Fifth Ed. Vol 5. A Wiley Interscience Publication. John Wiley \& Sons, Inc. New York.

Yuli Rahmini Suci. 2017. Perkembangan Umkm (Usaha Mikro Kecil dan Menengah) di Indonesia. Jurnal Ilmiah Cano Ekonomos, Vol. 6 No. 1 